\title{
Russian-Turkish cooperation in Syria: geopolitical alignment with limits
}

\author{
Seçkin Köstem \\ Bilkent University
}

\begin{abstract}
Russian and Turkish interests have clashed over Syria since the beginning of the conflict in late 2011. Yet, in Summer 2016, the two governments emerged as deal makers in the Syrian conflict. Due to a host of international and regional reasons, Russia and Turkey have enhanced cooperation on the ground in Syria. This article argues that the concept of alignment best captures the various forms of security cooperation taking shape in different regions of the world and is useful to explain Russian-Turkish security cooperation in Syria. It offers a detailed account of the origins and key components of Russian-Turkish geopolitical alignment in Syria. Military coordination and the search for a political settlement have been the salient components of this process. Cooperation in Syria has also had a spillover effect in other sectors. However, the article argues that Russian-Turkish geopolitical alignment is unlikely to transform into a more durable security partnership as the two countries continue to prefer divergent outcomes in Syria. Still, Russian-Turkish geopolitical alignment has significant implications for the regional order in an age of American decline.
\end{abstract}

\section{Introduction}

From the beginning of the Syrian conflict in 2011 until summer 2016, Russia and Turkey supported two radically opposed solutions in Syria. The downing of a Russian Su-24 fighter jet by Turkish air forces in November 2015 sparked a political crisis between the two countries with severe political and economic consequences for Turkey. By fall 2016, however, the two countries began to cooperate on ending the protracted civil war and humanitarian tragedy in Syria alongside agreeing to disagree on Bashar al-Assad's future. Through the Astana talks, Russia and Turkey, together with Iran, have been coordinating a joint ceasefire plan. Turkey has also conducted three cross-border military operations in Northern Syria since 2016 with Russian consent. Addressing Turkish ambassadors in Ankara in August 2018, Russian Minister of Foreign Affairs Sergei Lavrov said Russia and Turkey would take steps to 'enhance strategic partnership' as the international system 'is at a time of transition from bipolar order to multipolarization' (Xinhua 2018). Similarly, after a meeting with Lavrov in Moscow in August 2018, Turkish Minister of Foreign Affairs Mevlüt Çavuşoğlu referred to Russia as a 'strategic partner for Turkey' (T24 2018).

So far, the literature has not addressed Russian-Turkish cooperation in Syria through a conceptual lens. This article aims to fill this gap by exploring the ever-growing cooperation between Ankara and Moscow since Summer 
2016 through the concept of alignment. This article supports the argument of the burgeoning literature that the concept of 'alignment' best captures the various forms of security cooperation taking shape in different regions of the world (Chidley 2014; Korolev 2019; Menon 2007; Wilkins 2008, 2012). This article follows Snyder's $(1997,6)$ definition of alignment as "expectations of states about whether they will be supported or opposed by other states in future interactions". As such, an alignment with other states "involves mutual expectations of some degree of policy coordination on security issues under certain conditions in the future" (David 1991 and Walt 1987 as cited in Miller \& Toritsyn 2005, 333). In this conceptualization, alliance is a subset of alignment behavior and not all forms of security cooperation can be characterized as alliances (Snyder 1997, 8). Alignment also incurs a broader meaning than partnerships built solely on security cooperation (Chidley 2014, 147-151). The international system is undergoing a transformation in which alliances marked by formal defense treaties and mutual commitments no longer offer solutions to immediate security threats. In response, states have formed coalitions or strategic partnerships (Wilkins 2012) or engaged in soft-balancing behavior (Paul 2018), which offer greater flexibility in achieving their strategic goals.

Russia and Turkey are no strangers to this trend. Since 2016, RussianTurkish cooperation has rapidly transformed into a new form of informal geopolitical alignment. Notably, it has included a deeper institutional component than ever before in bilateral relations and closer military coordination on the ground, supported by close personal ties between presidents Putin and Erdoğan. Russian-Turkish alignment in Syria is informal as it does not rest upon a formal defense agreement. In addition, it is a geopolitical alignment because these two states have engaged in policy coordination over the resolution of a geopolitical crisis that has, since its outbreak in 2011, involved multiple great powers, regional powers as well as violent non-state actors. ${ }^{1}$ In Syria, the two countries have for the first time engaged in military coordination and worked on a joint political settlement plan. Cooperation with Russia over the Syrian conflict was a necessity for Turkey, rather than a choice due to a host of domestic and regional factors that emerged in 2015-16. Since 2015, Turkey has been primarily driven by countering the YPG threat in Syria. Gradually, its three military operations have allowed the country to sustain its influence in a sphere of influence in Northwestern and Northeastern Syria. Conversely, by cooperating with Turkey, Russia has aimed to indirectly control the Turkish-backed rebel forces, undermine the transatlantic alliance and ultimately serve its strategic purpose of preventing Western-led regime change. The geopolitical alignment over the Syrian conflict has had a spill-over effect on other sectors of cooperation, most importantly, in the defense sector as Turkey has purchased Russian S-400 air defense system. Despite this, this article also demonstrates that the current alignment is not problem-free and there are important obstacles for the transformation of this informal alignment into a more durable form of partnership.

Beyond Syria, Moscow's appeal for Ankara has both domestic political and international reasons. Domestically, Putin's support has been vital for Erdoğan

\footnotetext{
${ }^{1}$ See Phillips (2017) for the positions of various states and non-state actors in the Syrian conflict
} 
after the attempted coup of July 2016. Indeed, Moscow's traditional policy of preventing regime change through external intervention has resonated with the Turkish government's skepticism towards the role of the U.S. in the failed coup attempt. Ankara has embraced authoritarian principles that favor a Russian-style top-down executive control and the erosion of independent media, freedom of speech and strong civil society. In terms of the international order, the Turkish government has moved closer to the Russian position on multipolarity in the past decade. Turkey's growing isolation from the West due to its geopolitical rupture with the U.S. over Syria, as well as its ongoing rift with the EU can be clear signs for a reorientation of Turkey's foreign policy goals (Erşen \& Köstem 2019). In this context, the two governments have attempted to reconcile their differences over the current shape and the future of the Syrian conflict. How far the current alignment can endure will depend on whether Ankara and Moscow will be able to agree on a common goal in Syria and regional politics.

This article is structured as follows. Having outlined the context, the second section examines the literature on Russian-Turkish relations. The third section discusses the causes and key components of Russian-Turkish alignment in Syria in detail. The fourth section explores the divergences between Russia and Turkey in Syria. The concluding section summarizes the argument and discusses the theoretical and policy implications of Russian-Turkish alignment.

\section{The literature on Russian-Turkish relations in the $21^{\text {st }}$ century}

Russian-Turkish relations have drawn significant attention in the academic literature over the past two decades. The literature has paid particular attention to the co-existence of a deepening of economic cooperation and geopolitical rivalry between Moscow and Ankara in the Caucasus, the Black Sea and Central Asia. Bazoğlu Sezer $(2000,62)$, for instance, argued that the RussianTurkish relationship in the post-Cold War period was a "virtual rapprochement" such that the growing economic interdependence between the two countries was shadowed by "a hard kernel of mutual fear, mistrust, and suspicion". By the turn of the millennium, relations had already evolved from geopolitical rivalry in the Caucasus and Central Asia towards "multidimensional partnership" (Erşen 2011). The first discussion of the potential emergence of a "strategic partnership" or "axis" between the two countries dates back to the Iraq War of 2003. For example, Hill and Taspinar (2006, 90) referred to Russia and Turkey as the "axis of the excluded", arguing that these two natural rivals intensified cooperation due to a mutual need to prevent a potential American intervention in the Black Sea region and the Middle East. Similarly, Aktürk (2006) argued that the diminution of the Russian threat and Turkey's growing relative capabilities laid the ground for the strengthening of bilateral cooperation in the post-Cold War era. Indeed, he argued that the bilateral relationship transformed into a "strategic partnership" in the early 2000s due to cooperation in anti-terrorism, defense industry, and opposition to Iraq War (Aktürk 2006, 338, 346).

Later on, in 2009-2010, Russia and Turkey found a common ground to deepen their economic ties amidst the global financial crisis and looming Eurozone crisis (Erşen 2011, 2017a). This second period also corresponded to 
an era during which a potential "shift of axis" in Turkish foreign policy was debated, which witnessed a seeming shift from strategic alignment with the transatlantic world to a more independent foreign policy course (Öniş \& Yilmaz 2009). However, at the broader geopolitical context, Russia's annexation of Crimea in 2014 shifted the delicate military balance in the Black Sea in favor of Russia, making it "the indisputable hegemon of the Black Sea basin" (Aktürk 2014, 19). Ankara has consistently referred to Russia's action as a clear violation of international law and supported Crimean Tatars, whose political leaders took refuge in Kyiv after the annexation. Moreover, the two countries have opposing views on the conflict in eastern Ukraine, the Russo-Georgian War of 2008, the status of Abkhazia and South Ossetia, and the ongoing tensions in Nagorno-Karabakh. For these reasons, Öniş \& Y1lmaz (2016, 81-87) cautioned against referring to Russian-Turkish cooperation as a case of "strategic partnership". More recently, Baev (2019, 48-49) has argued that a lack of mutual trust and geopolitical divergences will prevent a closer partnership between these two major Black Sea powers.

Until the Syrian conflict, economic cooperation rather than strategic ties constituted the priority in Russian-Turkish relations (Svarin 2015; Öniş \& Yilmaz 2016). The two countries managed to "compartmentalize" bilateral ties such that disagreements over regional crises would not prevent economic cooperation, and strategic and economic issues would be handled in isolation from each other. The intensification of energy cooperation has been a crucial component of Russian-Turkish relations. In the past decade, Turkey has become Gazprom's second biggest customer after Germany (Köstem 2018, 16). Conversely, Russia's ongoing crisis with Ukraine has boosted Turkey's geopolitical importance for the delivery of Russian natural gas to European markets. As exemplified by the "TurkStream" pipeline project, Russia sees Turkey as an important energy partner in bypassing Ukraine as a transit corridor for its natural gas. As analyzed in the literature, this economic cooperation embodies characteristics of "asymmetric interdependence" in favor of Russia, due to the structural imbalances in trade emanating from Turkey's reliance on Russian natural gas (Öniş \& Yilmaz 2016; Köstem 2018). At the same time, RussianTurkish bilateral cooperation has enjoyed gradual but substantial institutionalization. In 2010, Ankara initiated the High-Level Cooperation Council, which brought together Putin and Erdoğan at annual summits, besides various ministers and senior bureaucrats to exchange views and coordinate policies on energy, tourism, trade, as well as cultural and humanitarian ties (Svarin 2015, 384).

Russian-Turkish cooperation in Syria, which has been underway since August 2016, is the latest phase of cooperation between the two countries under increasingly complex circumstances. The Syrian crisis has pushed the two countries towards working on a joint ceasefire plan - which has been replete with difficulties - and coordinating their military forces and intelligence organizations on the ground. The jet crisis of November 2015 and the following "strategic dialogue" in Syria has also practically ended the compartmentalization that had marked bilateral ties in the preceding two decades (Erşen 2017c). The next section turns to the causes and the key components of Russian-Turkish geopolitical alignment over the Syrian conflict. 


\section{Origins and key components of Russian-Turkish geopolitical alignment in Syria}

\section{Origins of alignment}

The nature of the Russian-Turkish alignment in Syria cannot be fully understood without highlighting the fighter jet crisis that preceded it. On 24 November 2015, Turkish F16 fighters shot down a Russian Su-24 which, according to the official explanation of the Turkish military, had violated Turkish airspace for seventeen seconds (Hürriyet Daily News 2015). This incident sparked a crisis between Ankara and Moscow and began a chain of developments that ultimately led to a radical shift in Turkey's Syria policy. In retaliation, Russia imposed economic sanctions on the Turkish economy, targeting its exports of fruits and vegetables, and Turkish investments in Russia (Köstem 2018). Russia also cancelled visa-free travel for Turkish citizens and targeted the Turkish tourism sector, which hosted 3 million Russians in 2014. Putin stated he felt "backstabbed by terrorist accomplices" and accused Turkey of supporting ISIS militarily and financially (Russia Today 2015). More importantly, Russia established a "de facto no-fly zone" for Turkish fighter jets over Syria thanks to its S-400 surface-to-air missiles deployed at the Khmeimim airbase close to the Northwestern Syrian town of Latakia (Stepanova 2016). Finally, Moscow increased its support of the Kurdish YPG fighters in Syria. For instance, the Democratic Union Party (PYD), which according to Ankara is an offshoot of the outlawed PKK, opened its first office abroad in Moscow in February 2016. Furthermore, Moscow has insisted that the Kurds participate in the Geneva talks to achieve a sustainable solution on the ground. In return, Ankara accused Moscow of bombing civilians and the moderate rebels in Syria, especially in the largely Turkmen populated Northwest, where the Russian Su-24 was shot down. Erdoğan also claimed that the weapons captured in Turkey's southeast from the PKK were Russian made (BBC Monitoring European 2016).

Soon, it became apparent to Ankara that a protracted crisis with Moscow would have dire consequences not only for Turkey's exporters, investors and domestic tourism sector, but also for its national security. Without close cooperation with Russia, it became increasingly difficult for Turkey to protect its borders from infiltration of forces linked with ISIS and YPG (Parlar Dal 2016, 1399-1402). In June 2016, Erdoğan wrote a letter of regret, which Erdoğan's spokesperson Ibrahim Kalın and then Kazakh president Nursultan Nazarbayev delivered to Putin in Tashkent at the Shanghai Cooperation Organization's summit (Yetkin 2016). With Putin accepting Erdoğan's proposal, Turkish-Russian cooperation entered a new stage, with rapid and important consequences for the Syrian crisis. Ultimately, the resolution of the jet crisis has offered Ankara the opportunity to control its long border with Syria and prevent what it saw as a potential for terrorist attacks inside Turkey originating from Syrian territory.

After Russian intervention in Syria in September 2015, Turkey's strategic priorities evolved dramatically from toppling the Assad regime to preventing attacks from the YPG and ISIS inside Turkey as well as the formation of a unified corridor in Northern Syria under YPG control. Therefore, Turkey tried to convince Russia that the Kurdish-led YPG's westwards move had to be 
stopped. Moreover, between 2014 and 2016 ISIS carried out a set of violent terrorist attacks in Turkey in towns such as Ankara, Diyarbakır, Gaziantep, Istanbul and Suruç, killing hundreds of civilians. Ankara was adamant to repel ISIS out of the area between the Azaz province of Northwest Syria and the Euphrates River. In return, Ankara was willing to establish a secure zone in Northern Syria cleared from ISIS with Turkish Armed Forces (TAF) and Ankara-backed Free Syrian Army (FSA) fighters. With the threat of Russian S-400s removed, Turkish fighter jets would have a freer hand in conducting operations against ISIS targets.

Ankara's changing policy vis-à-vis its own Kurdish question has contributed to this geopolitical pivot to Russia. In Summer 2015, the "solution process" between Ankara and the PKK, which had started in 2013, came to an end. YPG's territorial gains and eventual announcement of autonomy in Northern Syria in early 2014 added to Ankara's anxiety about the formation of a Kurdish-led autonomous political entity in its southern neighborhood, which would pose a threat to Turkey's own territorial integrity (Rumelili \& Çelik 2017, 290). The mutual lack of trust between Ankara and the PKK was exacerbated by the events around the siege of Kobane by ISIS in October 2014 that led to violent clashes in Turkey's Kurdish-majority towns. While Turkey was widely criticized for not intervening in Kobane, the YPG defended the town and defeated ISIS, which allowed it to expand its territorial control in Northern Syria (Arslan 2019, 425). Moreover, the siege of Kobane was a turning point for cementing the ties between the YPG and the U.S. (Arslan 2019, 425-426), which would then on be one of the major reasons for the RussianTurkish alignment.

In the general elections of June 2015, the ruling JDP's votes fell to $41 \%$ (Kemahlığlu 2015). That meant that JDP would not be able to control the majority of the parliament and would subsequently need a coalition partner to form a government for the first time since 2002. With the June 2015 election, a party that dominantly represents Kurds in Turkey, the People's Democratic Party (PDP), for the first time ran as a political party and won seats at the Turkish parliament (Kemahlıoğlu 2015, 446). PDP heavily criticized Ankara's position in the Syrian conflict vis-à-vis the YPG and ISIS, which especially came to light during the siege of Kobane. In July 2015, the peace process between the Turkish government and the PKK collapsed, which was followed by the government's operations against the PKK in major southeastern towns (Rumelili \& Çelik 2017). While the Turkish government accused the PKK of not abiding by the agreement to lay down arms, the PKK in return accused Ankara of not softening its policy vis-à-vis the Kurds (Baser 2017, 480). At the same time, the government increased its pressure on the pro-Kurdish PDP by removing 22 elected mayors from office in summer 2015 (Sayar1 2016, 272). The Turkish government aimed to garner support from nationalist voters and delegitimize the PDP due to its close ties with the PKK (Sayar1 2016). Amidst a resumption in the separatist conflict, Turkey went through another round of general elections in November 2015. As Sayarı (2016, 269-270) argued, snap elections of November 2015 took place 'in the shadow of the Kurdish conflict and the Syrian civil war' and the share of JDP votes increased to $49.5 \%$ to a significant extent due to increasing support from nationalist voters. The nationalist bloc has strengthened since then; Erdoğan won the presidential elections 
of June 2018 gathering 52\% of the votes thanks to a coalition he formed with the Nationalist Action Party.

The domestic political turmoil also strengthened Turkey's alignment with Russia. The growing 'competitive authoritarianism' in Turkish politics was accompanied by rising anti-Western views among the public opinion (Esen \& Gümüşçü 2016). Ultimately, Ankara wanted to prove it could find another strong and reliable partner, if the West did not take Turkey's concerns seriously. An important turning point in the Ankara-Moscow rapprochement was the failed coup attempt of July 2016. According to the Turkish government, this was organized by a group of Gulenist officers within the Turkish military. Amidst initial Western silence and lack of solidarity with Ankara, the Kremlin sided with Erdoğan immediately after the failed coup attempt.

In the past decade, Turkey's membership negotiations with the EU have stalled and the EU has sharply criticized problems related to the protection of human rights, freedom of speech, press freedom and minority rights in Turkey (see European Commission 2016). Contrary to Moscow, the EU harshly criticized the state of emergency, which the Turkish government announced in the wake of the attempted coup in July 2016 and called Turkey to lift it immediately (European Commission 2018, 3). In response, Ankara accused the EU of turning a blind eye on Turkey's security concerns. Moreover, Ankara has viewed the deterioration of its ties with the EU as Brussels' fault and criticized the EU for lack of will to incorporate Turkey and the slowing of its EU accession process.

The attempted coup of July 2016 has similarly worsened the rift between the U.S. and Turkey over the Syrian conflict and other regional geopolitical concerns. One particular source of disagreement emanates from the Turkish government's demand for the extradition of the U.S. based cleric Fetullah Gülen, the leader of the clandestine network, which Ankara alleges to be behind the failed coup. Conversely, Moscow banned the activities of the Gulenist network, officially called by Ankara the Gulenist terrorist organization (FETÖ), in Russia back in 2007 - long before Turkey's JDP and the Gulenist network broke up their political alliance. Amidst domestic political turmoil, Russia emerged as a reliable partner for Erdoğan and the JDP with no intention to interfere in Turkey's domestic political transformation (Erşen \& Köstem 2019, 6-8).

The solution of the Su-24 crisis and the subsequent cooperation in Syria was of strategic importance for Russia, too. Moscow has had the upper hand in making Ankara agree with the conditions that it set in Syria. As Ankara was struggling to recover from the negative economic consequences of Russian sanctions and the destabilizing effect of the failed coup attempt, Moscow felt stronger in convincing Ankara to come to terms on a ceasefire plan. In addition, Moscow viewed Turkey's support as instrumental since, from the beginning of the conflict, Russia was aware that a long-lasting solution in Syria could only come through with the participation of armed rebels, over which Turkey had leverage. This is consistent with the gradual "regionalization" of Russia's approach to the conflicts in the Middle East, whereby Moscow developed a pragmatic approach that enabled it to engage with all the major actors of the Syrian conflict regardless of whether their aims converged with Russia's (Stepanova 2018). 
The tripartite mechanism that Russia has established together with Turkey and Iran, and the Astana meetings, have boosted Russia's image as the most capable actor in Syria. With Turkish support, Russia would be able to present itself as a credible actor that was able to cooperate with a government that desired a diametrically opposed outcome in Syria. Finally, and most importantly, a partnership with Turkey, a NATO member, would demonstrate Russia's ability to undermine the transatlantic alliance. As the following section will suggest, Russia has capitalized upon Turkey's deteriorating ties with the U.S. in Syria.

\section{Military coordination}

Military coordination is the first practical component of the Russian-Turkish geopolitical alignment in Syria. In August 2016, representatives of the two states agreed to enhance trilateral cooperation between intelligence agencies, foreign ministries and chiefs of staff (Erşen 2017b). From then on, military units of both states in Syria exchanged information and started to coordinate their actions. For instance, since 2016, army chiefs, heads of intelligence agencies and ministers of defense have held regular meetings to coordinate developments in the field. This allowed Turkish Armed Forces (TAF) to start its first military operation in Syria, Operation Euphrates Shield, in August 2016 with Turkish-backed Turkmen and Arab armed elements of the FSA. Until Ankara ended the operation in March 2017, TAF and FSA captured Syrian towns such as Jarablus, Dabiq, Al Rai and Al Bab from ISIS. While raising concerns about Turkey's operation in Northern Syria, Russia has in general kept its reaction 'low-key' and has aimed to increase the coordination between Russian and Turkish armed forces (Erşen 2017b). By siding with Russia, Turkey was signaling to the U.S. and NATO that it would no longer wait for authorization from them in establishing a buffer zone in Northern Syria. Ankara was aiming to send a strong message to not only Washington, but also European capitals, which have become increasingly critical of growing authoritarianism in Turkey.

In January 2018, TAF waged its second military campaign in Syria, Operation Olive Branch, and this time in an attempt to clear the northwestern enclave of Afrin from the YPG. Just like Operation Euphrates Shield, Russian approval was the major prerequisite for a large offensive against the YPG forces, which had declared the establishment of an autonomous canton in the city in 2014. The Turkish Chief of General Staff and Head of National Intelligence Organization visited Moscow before the operation to get Russian approval of a Turkish armed offensive. Following the visit, Moscow "removed its de-facto security umbrella" for the YPG in Afrin and allowed Turkish fighter jets to control the area (International Crisis Group 2018, 22). Russia's approval was required because the YPG in Afrin, in contrast to those in Manbij, were protected by Russian military forces on the ground as well as Russian air force (International Crisis Group, 22). As opposed to siding with the YPG, Russia consented to Turkey's demand and did not prevent it from starting an armed campaign with the FSA. Indeed, Moscow rejected the Assad regime's call for preventing a Turkish offensive in Afrin, which demonstrated 
the importance of having Turkey on its side in managing the Syrian conflict (International Crisis Group 2018, 22).

Turkish forces and FSA captured Afrin town center in March 2018. Moscow accused Washington of creating the conditions for the situation in Afrin. In an interview with the Russian daily Kommersant (2018), Lavrov criticized the Americans for "infuriating Turkey" due to their unilateral acts in Syria. In return for Moscow's silence over Turkish military operations in Syria, Ankara shied away from openly criticizing Moscow as the Russia-backed forces of the Assad regime cleared Eastern Ghouta from Islamist rebels starting February 2018 and claimed total control of the town in April 2018. Close military coordination with Russia has enabled Turkey to quickly shift its focus from countering what it perceived as terrorist threats to establishing a sphere of influence backed by its armed forces in Northwestern Syria. The area that Turkey controls together with the rebel forces that it backs is narrower compared to Russian and American spheres of influence. However, Ankara seems to believe that it will help them to have a seat at the negotiation table for a future political settlement in Syria. Russian-Turkish military coordination took on a new dimension in October 2019 with Turkey's third military operation in Syria, the Operation Peace Spring, which the will paper will turn to in the fourth section.

\section{The search for a political settlement}

In addition to coordination between militaries, Ankara and Moscow have worked on a joint political process to end the Syrian conflict since late 2016. In early December 2016, the two governments agreed on a plan to evacuate civilians from Aleppo as clashes between the Assad regime's armed forces, Iranian-backed militias and rebel groups intensified. Despite the assassination of Russian ambassador in Ankara, Andrey Karlov, by an off-duty Turkish policy officer on December 19, 2016, Moscow and Ankara stepped up their efforts to reach a political solution to the Syrian crisis. On December 20, 2016, the Ministers of Foreign Affairs of Russia, Turkey and Iran signed the Moscow Declaration, a joint statement which put forward a roadmap for an end to the Syrian $^{\text {crisis. }}{ }^{2}$

The most important outcome of the two countries' cooperation was the Astana process. According to Stepanova $(2018,10)$, through the Astana process, Russia and Turkey (and to a lesser extent Iran) addressed three problems that the Geneva format had failed to solve: involve the major actors of the armed opposition, develop a lasting ceasefire plan, and take into account the interests of the major regional actors. While Turkey convinced many rebel factions including the Islamist Ahrar al-Sham to attend the talks, Russia convinced Iran and the Assad regime to sit at the negotiation table, although the latter declined to engage in direct talks with the representatives of the rebels. Moreover, as Pieper (2019, 378) argued Russia and the guarantors of the Astana process were effectively excluding the U.S. from discussions for postconflict settlement in Syria. At the same time, despite its leading role in the

\footnotetext{
${ }^{2}$ For full text of the declaration see The Ministry of Foreign Affairs of the Russian Federation (2016).
} 
Astana process, Russia has stressed that it saw the Security Council Resolution 2254 of December 2015 as the key document in offering a roadmap for peace and political transition in Syria. ${ }^{3}$ In other words, while Astana is a tactical achievement for Moscow, strategic victory will come through a larger setting such as Geneva talks, in which Western powers including the U.S., Germany and France will also be at the negotiation table.

In addition to the Astana process, Russian President Putin, Turkish President Erdoğan and Iranian President Rouhani have held five tripartite summits since November 2017 as heads of 'guarantor states'. As of October 2019, Russia and Turkey have held thirteen rounds of talks in Astana together with Iran. During the fourth round of the Astana talks in May 2017, the three countries agreed on the creation of four 'de-escalation zones' in Syria. The zones free from armed conflict and air strikes would include Idlib, Homs, Eastern Ghouta district of Damascus in which there was still active presence of the armed opposition, and south Syria including Daraa and Quneitra (TASS 2017b). In October 2017, TAF entered Northwestern Syria as part of the plan to create a de-escalation zone in Idlib. By May 2018, TAF established twelve observation points in the Idlib region. As the section on the obstacles for a durable partnership will demonstrate, the search for a political settlement has not been problem-free. While Ankara acquiesced over the Assad regime's military victories against the rebels elsewhere, Idlib has continued to be a source of disagreement between Ankara and Moscow.

\section{Cooperation beyond Syria}

While the Syrian conflict has been the main driving force of Russian-Turkish geopolitical alignment since August 2016, cooperation in nuclear energy and defense sector has added a multidimensional character to it. In addition to the High-Level Cooperation Council, which has held eight summits from 2010 to summer 2019, Presidents Putin and Erdoğan have met on various occasions to coordinate joint projects. Ankara and Moscow agreed on the construction of the Akkuyu Nuclear Power Plant back in 2010. While the project came to a temporary halt during the fighter jet crisis, its resolution has strengthened both governments' commitment to its completion. In a meeting with Erdoğan held in Sochi in November 2017, Putin announced that all impediments before the normalization of relations were lifted. In April 2018, during Putin's visit to Turkey, the two leaders took part in the groundbreaking ceremony of the Akkuyu nuclear power plant. While initially the Russian atomic agency Rosatom planned to construct, own and operate the power plant, in April 2019 it was reported that it aims to sell a $49 \%$ stake in the project (TASS 2019b). Upon completion, the Akkuyu power plant will be Turkey's first nuclear power plant. It is estimated that the new power plant will provide $7-10 \%$ of Turkey's annual energy need.

Russian-Turkish alignment over Syria has also prepared the groundwork for closer cooperation in the defense sector. Ankara has been in search for an air defense system for a long time. As the Syrian conflict exacerbated Ankara's

\footnotetext{
${ }^{3}$ See United Nations (2015).
} 
concerns about ballistic missiles, NATO deployed Patriot batteries and missile radar systems in Turkey starting 2012 (Egeli 2019, 73). In 2013, Ankara reached a deal with the Chinese state-owned CPMIEC to buy the FD-2000 long-range missile defense system as a result of a tender also joined by the Italian-French Eurosam and the U.S. CPMIEC was on the U.S. sanctions list and Washington clearly warned Ankara of the potential risks involved if it went ahead with the Chinese air defense system. In November 2015, Ankara cancelled the deal due to problems about technology transfer, interoperability with the NATO defense structure and complex foreign policy ramifications (Egeli 2019, 74-78).

In 2017, Erdogan announced that Ankara reached a deal with Moscow on purchasing the Russian S-400 air defense system and made a down payment for the missiles. It has since become apparent that the deal is worth $\$ 2.5$ billion, and Russia will provide loans for up to 55\% of the total amount (Reuters 2017). Ankara's decision to buy the missiles from Russia has met fierce reaction from the U.S. and NATO. The deployment of S-400s in Turkey would complicate Turkey's coordination with other members of the transatlantic alliance as S-400 systems cannot be integrated with NATO structures. More worrying for the transatlantic alliance is the potential for the deployment of Russian S-400s in Turkey to expose NATO's F-35 program to potential cyberhacking and digital espionage (Kasapoğlu \& Ülgen 2018). Ankara has countered NATO's concerns on the friend and foe identification mechanism by arguing that the S-400s will be kept as a standalone system and will therefore not pose any threat to NATO. In response to Turkey's decision to purchase the S-400s, the U.S. State Department announced a plan to sell Patriot missile defense systems to Turkey in December 2018. The U.S. has also threatened Turkey to be excluded from the F-35 project, as well as to impose deeper sanctions under the CAATSA ${ }^{4}$, a law that aims to prohibit engaging with Russian intelligence and defense sectors. As a sign of Washington's insistent position, the Pentagon stopped the delivery of F-35 parts to Turkey in March 2019.

Ankara has demonstrated its resolve on its purchase of the S-400s in summer 2019. The first deployment of S-400 batteries started in July 2019, and Turkish air force and personnel started to receive training for the missiles in Russia in September 2019. In response, the U.S. has suspended Turkey's partnership in the F-35 program in July 2019. Turkey has been a program partner of the F-35 project since 1999, and several Turkish defense companies have taken part in the production of the F-35 fighter coordinated by Lockheed Martin since 2004. As of writing, Washington has not yet triggered CAATSA sanctions against Ankara, and the Turkish government has been negotiating with the Trump administration to avoid sanctions that go beyond Turkey's exclusion from the F-35 program.

Moscow has announced that the contract allows "partial transfer of production technologies to the Turkish side" (TASS 2019c), while not all the details of the detail have been disclosed to the public. As a sign of growing desire on Turkey's side to deepen defense cooperation with Russia, in August 2019 Erdogan attended the annual Russian aviation and space fair, MAKS-2019. During the visit, Erdoğan and Putin reportedly discussed Turkey's potential purchase of Russian Su-35 fighter jet and the Su-57 stealth fighter jet. While it

\footnotetext{
${ }^{4}$ Countering America's Adversaries Through Sanctions Act.
} 
is premature to speculate on the issue yet, one can predict that Ankara might want to use Russian fighter jets as a bargaining tool for its removal from the F-35 program. Turkey's decision to purchase an air defense system from Russia implicates a new form of geopolitical alignment between Russia and Turkey. Its determination in purchasing the S-400s also demonstrates the appeal of Russia's call for multipolarity for the Turkish government. Turkey's exclusion from the F-35 and potential U.S. sanctions that can follow will definitely push Ankara closer to Moscow and exacerbate the growing antiAmericanism in Turkey. The deployment of advanced Russian weaponry in Turkey could also lead to frictions within NATO and result in Turkey's eventual isolation from the transatlantic alliance.

\section{Obstacles for a durable security partnership between Russia and Turkey}

Despite the above-mentioned factors that have moved Russia and Turkey ever closer to each other since summer 2016, these two countries continue to prefer different outcomes in Syria, which might be too difficult to be reconciled. The commonly held belief in being excluded by the West notwithstanding, Russia and Turkey do not have a common cause that will bind them together in Syria and other regions. Despite its deteriorating ties with the U.S., Turkey has supported the anti-Assad policies of the U.S. and consistently searched for ways to convince the Trump administration on dropping its support for the YPG forces (see for instance Gall 2018, Hürriyet Daily News 2018). The status of Syrian Kurds, the political future of Bashar al Assad, the presence of Turkish forces in Northern Syria, divergent positions over Idlib and Russia's ties with Iran might prevent the transformation of Russian-Turkish cooperation in Syria into a more durable security partnership. Outside Syria, Russian and Turkish interests will continue to clash on all the active and frozen conflicts in the Post-Soviet space including Eastern Ukraine, Crimea, Abkhazia, South Ossetia and Nagorno-Karabakh as well as in Libya.

The U.S. has played an indirect, but an essential role in preparing the conditions for the current Russian-Turkish alignment. Due to the aforementioned dimensions of Turkey's Kurdish question, U.S. support to the YPG in the fight against ISIS under both Obama and Trump administrations has exacerbated Turkey's concerns for the future of Syria. Russia, on the other hand, became the major actor shaping the fate of the Syrian conflict in the absence of a stronger U.S. role in the conflict. At the same time, despite the tensions in TurkishAmerican relations, Ankara plays a careful balancing game between Washington and Moscow. For example, Erdoğan's spokesperson Ibrahim Kalın stated that Ankara did not see international relations in zero-sum terms, and that the current Russian-Turkish cooperation did not come at the expense of Turkey's alliance with NATO and the U.S. (Financial Times 2017a).

Despite the strategic rapprochement, Ankara and Moscow's positions diverged in the aftermath of the chemical attack in Idlib, which killed more than fifty civilians in April 2017. President Trump ordered an attack on the Syrian military base near the city of Homs, from which the fighter jets that carried out the chemical attack had allegedly taken off. In addition to immediately accusing the Assad regime for committing the attack, Ankara welcomed the American strike (Anadolu Agency 2017). Ankara has also sided with the 
U.S., Britain and France as the three allies launched missiles to hit Syrian military targets in April 2018. Conversely, Moscow criticized the strikes for violating international law. Applauding Turkey's positive reaction to the strikes, French President Macron said they were finally able to separate Turkey from Russia (Reuters 2018a). In response, Turkish Minister of Foreign Affairs Çavuşoğlu said Turkey's ties with Russia were too strong to be broken by France (Daily Sabah 2018).

The status of Syrian Kurds and the shape of the future political settlement in Syria can also haunt the prospects of a more durable partnership between Russia and Turkey. Ankara has continued to be strictly against a confederative solution in Syria even after its rapprochement with Russia. That was primarily because Turkey's key priority in Syria has transformed, as demonstrated with Operations Euphrates Shield, Olive Branch and Peace Spring, from toppling the Assad regime to preventing the unification of Kurdish cantons (self-governments) in Northern Syria under the PYD/YPG flag. Due to Turkey's resistance, the PYD has so far not participated in the Astana talks. However, Russia has several times expressed its desire to include the PYD in the peace process. In late January 2017, right after the first round of the talks, Moscow hosted PYD officials to discuss the future of political transition in Syria. The draft Syrian constitution that Moscow prepared offers 'cultural autonomy' to Syrian Kurds (Sputnik News 2017). In response to the Turkish government's call for clarifying this vague term, the Kremlin has argued it only includes the right to access education and governmental services in Kurdish, as the draft agreement grants similar rights for other Syrian minorities with respect to their own languages.

More importantly, Moscow has insisted that the PYD should be invited to the Geneva talks. Mikhail Bogdanov, Russia's deputy minister of foreign affairs and special envoy to the Middle East, has criticized the Geneva talks for failing to ensure broad representation of the Syrian opposition due to Kurds' absence (TASS 2017a). Moreover, Ankara's demands for its closure the PYD office in Moscow, which was opened in February 2016 after the Su-24 crisis, have not been met. Furthermore, Russia does not refer to the PYD or the YPG as terrorist organizations in Syria and the joint statements by Putin, Erdoğan and Rouhani only include ISIS and Al-Nusra Front as such (see President of Russia 2018a). So far, Ankara has resisted the participation of the PYD in the constitutional committee for the future political settlement in Syria, a problem that the United Nations' special envoy to Syria Staffan de Mistura has acknowledged during Astana talks (Reuters 2018b).

The process that started with the Trump administration's announcement of a withdrawal of U.S. troops from Syria first in December 2018 and then in October 2019 has also shaped Russian-Turkish cooperation on the ground. Ankara has been adamant to push the YPG forces to the east of the Euphrates region, ultimately interrupting a potential unified corridor controlled by the YPG from the Iraqi border to the Syrian town of Manbij. From early 2019 to October 2019, Turkish and American governments worked on the establishment of a safe zone in Northeast Syria, as part of Washington's efforts to ease Ankara's concerns on the threat they see in the YPG. Initially, the safe zone was planned to cover 460 kilometers along the Turkish-Syrian border and run 32 kilometers deep into Syrian territory. The Turkish government has also seen 
the establishment of a safe zone as an opportunity to resettle refugees, whose numbers in Turkey has been growing since the conflict began. Official numbers indicate the presence of 3,6 million Syrians in Turkey as of October 2019. As Erdoğan announced at the UN General Assembly in September 2019, Ankara aims to resettle "somewhere between 1 to 2 million refugees" in an expanded safe zone (The Guardian 2019a). While Ankara argues that the safe zone should be under Turkish control, from Moscow's perspective, Damascus should be in full charge of the zone's security (DW 2019). In October 2019, President Trump announced that the U.S. forces would not stand in the way of TAF during the latter's long-awaited offensive in Northern Syria. Following Trump's decision, TAF started its third offensive in Syria, the Operation Peace Spring, with the aim of clearing YPG forces from Northeastern Syrian towns of Tal Abyad and Ras Al Ayn (The Guardian 2019b).

Despite its passive support for Turkey's three military operations in Syria, it is unclear whether Moscow will tolerate the longer-term presence of Turkish troops in Syria. Putin has clearly stated several times that he does not welcome the presence of foreign troops in Syria, especially those without the invitation of Damascus (Qiblawi 2018, Reuters 2019c). Both Turkey and the YPG's acquiescence to the Russian plan has been vital for Putin's plan to re-unite Syria under the Assad regime. For Moscow, the ideal scenario would be the YPG's acceptance of the superiority of the Assad regime without any significant preconditions. However, given the presence of U.S. troops in Northeastern Syria, and its own ties with the YPG, the second-best scenario for Moscow would be the YPG's acceptance of the regime's superiority in return for Assad's approval of an autonomy for Northeastern Syria under Kurdish influence. In January 2019, during a meeting with Erdoğan in Moscow, Putin stated that the Adana Protocol of 1998 was still in effect and should constitute the legal basis for addressing Turkey's security concerns (TASS 2019a). With the Adana Protocol, then President of Syria, Hafez al Assad had agreed to end Syria's military, logistical and financial support to the PKK, declare the PKK a terrorist organization and ban the PKK activities in Syrian territory. By bringing the alreadydefunct Adana Protocol to the agenda, Putin has aimed to establish links between Ankara and Damascus and prevent a Turkish-American deal on the establishment of a safe zone in Northeastern Syria. While Moscow has continued to promote the Adana Protocol, it has also tacitly consented to TAF's third military operation in Syria, the Operation Peace Spring. Setting out Moscow's perspective on Turkey's third military operation, the Kremlin spokesperson Dmitry Peskov stated that the Kremlin expected Ankara to "refrain from any actions that may create obstacles on the path of Syrian settlement" now that the Syrian Constitutional Committee has been formed (Suchkov 2019).

Turkish and American governments reached a ceasefire agreement that suspended the Operation Peace Spring on October 17, 2019 eight days after the operation started. That was followed by a memorandum between Erdoğan and Putin in Sochi on October 22. In Sochi, Russia agreed to the status quo established by Turkey's military operation "covering Tal Abyad and Ras Al Ayn with a depth of $32 \mathrm{~km}$ (20 miles)" (President of Russia 2019). Moscow also committed to the removal of YPG forces and their weapons from Manbij and Tal Rifat. In return, Ankara accepted the Assad regime's takeover of towns formerly controlled by the YPG. All in all, this process has served Russia's 
purposes of pushing the YPG to accept the Assad regime's superiority as well as convincing the Turkish government to consent to the regime's rule in Northern Syria. In the foreseeable future, Moscow will continue to look for opportunities to push the YPG closer to the Assad regime politically and create the conditions for a rapprochement between Ankara and Damascus. The Sochi memorandum of October 2019 has also resulted in a deepening of military coordination between Russia and Turkey as the two countries started joint patrols in Northeastern Syria. The joint patrols have aimed to assure the removal of YPG militants from the west and the east of the Operation Peace Spring. It is yet to be seen if Ankara will continue to acquiesce to Moscow's relationship with the YPG.

Disagreement over Idlib has been another source of tension between Turkey and Russia. Since December 2017, Assad's forces have moved towards Idlib, a stronghold of the Hay'at Tahrir al Sham (HTS) militant group. HTS, which is a rebranded form of the al-Qaida linked al-Nusra front, is among the militant groups that were left out of the ceasefire plan agreed upon by Russia, Turkey and Iran. In the Tehran summit of September 2018 that brought together Putin, Erdoğan and Rouhani, Turkey's disagreement with Russia and Iran with regard to Idlib once again came to light. Emphasizing the threat that civilians face, Erdoğan insisted on a joint announcement of a ceasefire in Idlib, a de-escalation zone under Turkey's responsibility.

From Moscow's perspective, Idlib is the only remaining terrorist hotbed in Syria, which should be eliminated before a long-lasting peace plan can be negotiated (TASS 2018). Writing for the Wall Street Journal after the summit, Erdoğan (2018 b) argued "if the Syrian regime attacks Idlib, the result will be a humanitarian and geopolitical disaster". The UN has several times warned of massive civilian casualties and a new wave of refugee flows to Turkey and Europe in case regime forces start their campaign over Idlib (BBC 2018). The U.S., UK and France have also demonstrated their support for the Turkish position. Despite the disappointment at the Tehran Summit, in September 2018 Putin and Erdogan agreed on establishing a buffer zone between the armed opposition and regime forces in Idlib. The two parties agreed on the establishment of a $15-20 \mathrm{~km}$ deep zone freed from heavy weapons including tanks, artillery and mortars (The Guardian 2018). Pursuing the goal of preventing a Russian-backed attack by the Assad regime in Idlib, Turkey pledged itself to the difficult task of observing the withdrawal of heavy weapons as well as HTS fighters away from the buffer zone (The Guardian 2018). In October 2018, Putin agreed on a lasting ceasefire over Idlib during a meeting with French President Macron, German Chancellor Merkel and Turkish President Erdogan in Istanbul (President of Russia 2018b).

Moscow has gradually increased its criticism over Ankara's inability to stop the activities of HTS in Idlib (The Moscow Times 2019, Kommersant 2019). In April 2019, regime forces backed by Russian air power started an armed offensive to capture Idlib and the surrounding cities (Reuters 2019a). In response, Ankara has increased its logistical support to the National Liberation Front, a rebel group it has been supporting against the Assad regime (Reuters 2019a). The Assad regime's attacks in Idlib intensified in summer 2019, putting Turkish troops on the ground at risk of confrontation with regime forces. In August 2019, Russian-backed regime forces captured the strategically located 
town of Khan Sheikhoun from HTS and later on encircled a Turkish observation post south of the town. At the same time, the Turkish government has continued its diplomatic efforts to convince the Kremlin on ending the Idlib campaign. Erdoğan and the Turkish government have continued to criticize the Assad regime for bombing civilians and warned of a looming humanitarian tragedy. The Idlib campaign has exacerbated Ankara's concerns about a new wave of refugee flow to the Turkish border.

The Kremlin, however, has stuck to its original position on the Idlib issue. During Erdoğan's visit to the MAKS-2019 fair, Putin stated together with Erdoğan they outlined "additional joint steps to neutralize the terrorists' nests in Idlib and normalize the situation there and in the whole of Syria" (Reuters 2019b). The fifth trilateral summit that brought together Erdogan, Putin and Rouhani took place in Ankara in September 2019. At the summit, the three leaders agreed to form a Syrian Constitutional Committee, but there was no progress on the Idlib issue. Three days after the summit, Russia and China vetoed a draft UN Security Council resolution calling for a ceasefire in the region. The current deadlock in Idlib is unsustainable for Moscow and will eventually force the Kremlin to make a hard choice between backing the regime offensive and standing by Ankara's position.

Finally, Russia's partnership with Iran will be an important factor for the future course of Russian-Turkish cooperation in Syria. While Ankara has moved closer to Moscow and Tehran's position since summer 2016, it has also been concerned that Iran would try to disrupt the fragile ceasefire (Erssen 2017b). That could happen through Iran's continuing support to Shia militias against Turkey-backed Sunni rebels. In the foreseeable future, Iran will continue to be a staunch supporter of the Assad regime and the presence of Hezbollah and other Shia armed groups in Syria. Tehran has both supported the Astana process and continued to find ways to open a Shia corridor from the Iraqi border to Lebanon in order to directly link itself with Hezbollah (Financial Times 2017b). As the reported clashes between Russian troops and pro-Iranian militias in Aleppo demonstrate, Iran's military activity in Syria may become a potential spoiler for Russia's political transition plan as well (Dettmer 2019). There are also significant differences between Moscow and Tehran on the political future of Syria. Particularly, if Russia aims to sustain its role as the chief interlocutor in Syria, it will then have to assure Israel on the role that Iran as well as the Iranian-backed Hezbollah and other militias will play in Syria's future.

\section{Conclusion}

This article has argued that Russian-Turkish cooperation in Syria is an informal geopolitical alignment that has added a new dimension to bilateral relations between these two traditional rivals. While their initial positions clashed, since summer 2016, Russia and Turkey have coordinated their military actions and worked on a joint political settlement in Syria. This process has had a spillover effect on other dimensions of cooperation, most importantly the defense sector as Turkey has purchased the Russian S-400 air defense system. While Turkey has been driven by countering what it sees as a threat of terrorism originating from Syria, preventing the unification of YPG-controlled towns 
and protecting a narrow sphere of influence in Northwestern and Northern Syria, Russia has aimed to secure victory for Damascus, prevent regime change in Syria, secure its place in the negotiation table with the West for the future of Syria and break the Transatlantic alliance. The article has also argued that this geopolitical alignment is unlikely to transform into a durable security partnership due to the divergent nature of the two countries' goals about the future of Syria.

Russian-Turkish cooperation in Syria allows for elaborating on the broader bilateral relationship between the two countries. In its current form, the Russian-Turkish geopolitical alignment is still too loose and lacks institutional depth despite the intensification of cooperation in multiple issue areas in the past two decades. At the same time, the factors that have enabled RussianTurkish cooperation in Syria will not disappear anytime soon. Many in the Kremlin interpret the ongoing tensions as part of an emerging rivalry between the "Old West" and "Greater Eurasia" (Karaganov 2016). This rivalry goes beyond a disagreement over Ukraine and Syria to include a clash of political and social values between the West and Russia (Lewis 2018). Similarly, a senior advisor to President Erdoğan argued that Turkey, Russia and Iran "carry Eurasia into the future" (Alkin 2018). As Erdoğan wrote in The New York Times in August 2018, the rift with the U.S. can push Turkey to "start looking for new friends and allies" (Erdoğan 2018a). Under increasing criticism from the West, closer cooperation with Russia will make President Erdoğan feel stronger in both domestic and international politics. The developments in the aftermath of the failed coup attempt of July 2016 has once again demonstrated the importance of finding a reliable partner outside the West for Erdoğan. Russia's goals of attaining a multipolar world order under Putin and preventing the West's interference with the domestic politics of authoritarian regimes have found a sympathetic audience in Ankara. If its deployment of Russian S-400s result in American sanctions, Turkey's geopolitical alignment with Russia can consolidate and go beyond cooperation in Syria.

Russian-Turkish cooperation in Syria today has important implications for the study of alignments as well as the future of the regional order. First, the literature on alignments typically addresses material factors behind two or more countries' decision to enhance strategic cooperation. In the case of Russian-Turkish alignment, not only material cost-benefit calculations, but also broader ideational factors as well as domestic political issues are at play. ${ }^{5}$ Turkey's changing approach to its Kurdish question since summer 2015, the failed coup attempt of July 2016 and the transition to a presidential system in 2017 have significantly affected its foreign policy choices. As Turkey's political system is getting more illiberal, its political identity might be moving closer to that of Russia's with no checks on executive power. According to Wilson (2019), the Russian-Chinese partnership has been cemented by the similarity of the two countries' political identities. Similar to Russia and China, increasingly since the failed coup attempt of July 2016, Turkey has also been more vocal for principles such as respect for sovereignty and non-interference in domestic politics. Finally, while the current partnership in Syria helps bolster Russia's

\footnotetext{
${ }^{5}$ See Chidley (2014) for a deeper analysis of other ideationally oriented types of alignment such as the India Africa Forum, IBSA and BRICS.
} 
self-perception as a great power, it also plays into Turkey's self-identification as a regional power, capable of influencing political outcomes in the Middle East.

Second, the article shows that in the absence of American leadership, a NATO member can intensify cooperation in regional security issues with NATO's key adversary, although the two country's initial positions and ultimate goals clash. The current cooperation in Syria have offered both Ankara and Moscow the opportunity to display strength to the West and demonstrate that they can work towards accomplishing strategic tasks without support from the U.S. or the EU. Third, Russian-Turkish cooperation in Syria provides evidence that rising powers that aim to challenge the Western-led global order might seek ways for deepening cooperation beyond economic matters. Russia and Turkey have for the first time in the post-Cold War era cooperated on a regional security issue in the Middle East, despite the continuation of a clash of interests in other regions such as the Black Sea and the Caucasus. Fourth, the American strategy in Syria has pushed an important NATO ally, Turkey closer to Russia. American support for the YPG has been instrumental in defeating ISIS, but it has also resulted in discontent and a loss of trust in Turkey vis-à-vis both the U.S. and NATO. This source of tension within the Western alliance might have important consequences for alignments in the Middle East and Eurasia and potentially even for the future of the Americanled global order.

\section{Acknowledgements}

The author would like to thank Elif Gökşen, Juliet Johnson, Emre Erşen, Pinar Ipek, Selver Şahin, Berk Esen as well as the editorial board and the five anonymous reviewers for valuable comments and suggestions.

\section{Notes on contributor}

Seçkin Köstem is Assistant Professor of International Relations at Bilkent University, Ankara. He received his PhD from McGill University in 2016. In Fall 2018, he was a George F. Kennan Fellow at the Kennan Institute in Washington, DC. He has been a visiting researcher at Columbia University's Harriman Institute, New York University's Jordan Center, King's College London's Russia Institute and the Moscow State Institute of International Relations (MGIMO). His research focuses on Russian and Turkish foreign economic policies, regional and rising powers, and Turkish-Russian relations. His articles have been published in journals such as Review of International Political Economy, Foreign Policy Analysis, Global Policy and Perceptions: Journal of International Affairs.

\section{References}

Aktürk, Şener (2006) 'Turkish-Russian Relations after the Cold War (1992-2002)', Turkish Studies, 7:3, 337-364

Aktürk, Sener (2014) 'Toward a Turkish-Russian axis? Conflicts in Georgia, Syria and Ukraine, and cooperation over nuclear energy', Insight Turkey, 16:4, 13-22 
Alkin, Kerem (2018) 'Turkey, Iran, Russia will carry Eurasia into the future', Daily Sabah, 7 April. <https://www.dailysabah.com/columns/alkin-kerem/2018/04/07/ turkey-iran-russia-will-carry-eurasia-into-the-future> accessed 5 November 2019

Anadolu Agency (2017) 'US strike on Assad regime a 'positive response': Erdogan aide', 7 April. <https://www.aa.com.tr/en/middle-east/us-strike-on-assadregime-a-positive-response-erdogan-aide/791216> accessed 5 June 2018

Arslan, Sinem (2019) 'Transborder Ethnic Kin and the Dynamics of Peace Processes: Insights from the Kurdish Conflict', Civil Wars, 21:3, 410-33

Baev, Pavel (2019) 'Turkey's Ambiguous Strategic Rapprochement with Russia' in Emre Erşen and Seçkin Köstem (eds) Turkey's pivot to eurasia: Geopolitics and foreign policy in a changing world order. (London \& New York: Routledge), 48-63

Baser, Bahar (2017) 'Intricacies of Engaging Diaspora Communities in Conflict Resolution and Transitional Justice: The Kurdish Diaspora and the Peace Process in Turkey', Civil Wars, 19:4, 470-94

Bazoğlu Sezer, Duygu (2000) 'Turkish-Russian Relations: The Challenges of Reconciling Geopolitical Competition with Economic Partnership', Turkish Studies, 1:1, 59-82

BBC (2018) 'Syria Idlib: UN warns of threat to civilians if new offensive begins', 30 August, <https://www.bbc.com/news/world-middle-east-45360053> accessed 5 September 2019

BBC Monitoring European (2016) 'Turkish president says arms seized in southeast Russian-made', 2 February

Chidley, Colleen (2014) 'Towards a Framework of Alignment in International Relations', Politikon, 41:1, 141-57

Daily Sabah (2018) 'Turkey-Russia ties too strong to be broken by Macron', 16 April, $<$ https://www.dailysabah.com/diplomacy/2018/04/16/turkey-russia-relationstoo-strong-to-be-broken-by-macron-fm-says $>$ accessed 10 June 2019

David, Steven R (1991) Choosing sides: Alignment and realignment in the third world. (Baltimore: Johns Hopkins University Press)

Dettmer, Jamie (2019) 'Russia, Iran Maneuver for Influence in Syria', Voice of America, 2 May, <https://www.voanews.com/a/russia-iran-maneuver-for-influence-in-syria/ 4900700.html> accessed 10 June 2019

DW (2019) 'Russia and Turkey Promise Coordination in Syria', 23 January, <https:// www.dw.com/en/russia-and-turkey-promise-coordination-in-syria/a-47202631> accessed 5 November 2019

Egeli, Sitki (2019) 'Making Sense of Turkey's Air and Defense Missile Merry-go-round', All Azimuth: A Journal of Foreign Policy and Peace, 8:1, 1-23

Erdoğan, Recep Tayyip (2018a) 'How Turkey sees the Crisis with the West', 10 August, The New York Times. <https://www.nytimes.com/2018/08/10/opinion/turkeyerdogan-trump-crisis-sanctions.html?action=click\&module=Opinion\&pgtype $=$ Home page $>$ accessed 10 June 2019

Erdoğan, Recep Tayyip (2018b) 'The World Must Stop Assad', The Wall Street Journal, 10 September

Erşen, Emre (2011) 'Turkey and Russia: An Emerging 'Strategic Axis' in Eurasia', EurOrient, 35-36, 263-85

Erşen, Emre (2017a) 'The Transatlantic Dimension of Turkey's Strategic Rapprochement with Russia', in Sasha Toperich and Aylin Unver Noi (eds), Turkey \& transatlantic relations baltimore (Washington, DC: Center for Transatlantic Relations, SAIS), 203-216

Erşen, Emre (2017b) 'The Turkish-Russian Dialogue in Syria: Prospects and Challenges', Alsharq Forum, 5 January, <http://sharqforum.org/2017/01/05/the-turkishrussian-dialogue-in-syria-prospects-and-challenges/> accessed 10 June 2019

Erşen, Emre (2017c) 'Evaluating the Fighter Jet crisis in Turkish-Russian Relations', Insight Turkey, 19:4, 85-103

Erşen, Emre, and Seçkin Köstem (2019) 'Introduction: Understanding the dynamics of Turkey's Pivot to Eurasia', in Emre Erşen \& Seçkin Köstem (eds), Turkey's pivot to eurasia: Geopolitics and foreign policy in a changing world order (London \& New York: Routledge), 1-14

Esen, Berk, and Sebnem Gumuscu (2016) 'Rising Competitive Authoritarianism in Turkey', Third World Quarterly, 37:9, 1581-606 
European Commission (2016) 'Commission Staff Working Document, Turkey 2016 Report', 9 November, <https://ec.europa.eu/neighbourhood-enlargement/sites/ near/files/pdf/key_documents/2016/20161109_report_turkey.pdf $>$ accessed 10 June 2019

European Commission (2018) 'Commission Staff Working Document, Turkey 2018 Report', 17 April, <https://ec.europa.eu/neighbourhood-enlargement/sites/near/ files/20180417-turkey-report.pdf> accessed 10 June 2019

Financial Times (2017a) 'Putin and Erdogan mend ties as Turkey scales back Syria goals', 13 January, <https://www.ft.com/content/2158449e-d9af-11e6-944be7eb37a6aa8e > accessed 10 June 2019

Financial Times (2017b) 'Syria de-escalation deal stirs fears of carve-up by foreign powers', 16 May, <https://www.ft.com/content/42aa4308-3941-11e7-821a6027b8a20f23> accessed 5 November 2019

Gall, Carlotta (2018) 'U.S. and Turkey agree on Kurds' withdrawal from Syrian town', 4 June, <https://www.nytimes.com/2018/06/04/world/middleeast/turkey-syriakurds-manbij.html> accessed 10 June 2019

Hill, Fiona, and Omer Taspinar (2006) 'Turkey and Russia: Axis of the excluded?', Survival, 48:1, 81-92

Hürriyet Daily News (2015) 'Two Russian Warplanes Violate Turkish Airspace for 17Seconds: Turkey', 25 November, <http://www.hurriyetdailynews.com/tworussian-warplanes-violated-turkish-airspace-for-17-seconds-turkey-91635> accessed 10 June 2019

Hürriyet Daily News (2018) 'US and Turkey to Cooperate in Syria's Liberated Zones', 18 February, <http://www.hurriyetdailynews.com/us-and-turkey-to-cooperate-insyrias-liberated-zones-mattis-127499> accessed 10 June 2019

International Crisis Group (2018) 'Prospects for a Deal to Stabilise Syria's North East', Middle East Report No 190, 5 September, Brussels

Karaganov, Sergei (2016) 'Global challenges and Russia's foreign policy', Strategic Analysis, 40:6, 461-73

Kasapoğlu, Can, and Sinan, Ülgen (2018) 'Is Turkey Sleepwalking out of the Alliance? An Assessment of th F-35 Deliveries and the S-400 Acquisition', Center for Economics and Foreign Policy Studies, August 2018. <http://edam.org.tr/wpcontent/uploads/2018/08/Is-Turkey-sleepwalking-out-of-NATO.pdf $>$ accessed 5 November 2019

Kemahlıoglu, Özge (2015) 'Winds of Change? The June 2015 Parliamentary Election in Turkey', South European Society and Politics, 20:4, 445-64

Kommersant (2018) 'Zaryazhennost' na rusofobiyu bespretsedentna', 22 January, <https://kommersant.ru/doc/3526872> accessed 5 November 2019

Kommersant (2019) 'Siriyskaya armiya peresmatrivayet granitsy', 23 August, <https:/ / www.kommersant.ru/doc/4068068> accessed 5 November 2019

Korolev, Alexander (2019) 'How Closely Aligned Are China and Russia? Measuring Strategic Cooperation in IR', International Politics, Online First, 1-30. DOI: $<$ https:doi.org/10.1057/s41311-019-00178-8

Köstem, Seçkin (2018) 'The Political Economy of Turkish-Russian Relations: Dynamics of Asymmetric Interdependence', Perceptions: Journal of International Affairs, 23:2, $10-32$

Lewis, David G (2018) 'Geopolitical Imaginaries in Russian Foreign Policy: The Evolution of 'Greater Eurasia', Europe-Asia Studies, 70:10, 1612-37

Menon, Rajan (2007) The end of alliances (New York: Oxford University Press)

Miller, Eric A, and A rkady Toritsyn (2005) 'Bringing the Leader Back In: Internal Threats and Alignment Theory in the Commonwealth of Independent States', Security Studies, 14:2, 325-63

Öniş, Ziya, and Şuhnaz Yılmaz (2009) 'Between Europeanization and Euro-Asianism: Foreign Policy Activism in Turkey during the AKP Era', Turkish Studies, 10:1, 7-24

Öniş, Ziya, and Şuhnaz Yllmaz (2016) 'Turkey and Russia in a shifting global order: cooperation, conflict and asymmetric interdependence in a turbulent region', Third World Quarterly, 37:1, 71-95 
Parlar Dal, Emel (2016) 'Impact of the Transnationalization of the Syrian civil war on Turkey: Conflict Spillover Cases of ISIS and PYD-YPG/PKK', Cambridge Review of International Affairs, 29:4, 1396-420

Paul, T.V (2018) Restraining great powers: Soft balancing in the age of U.S. Primacy (New Haven, CT: Yale University Press)

Phillips, Christopher (2017) The battle for syria: International rivalry in the new Middle east (New Haven, CT and London: Yale University Press)

Pieper, Moritz (2019) 'Rising Power' Status and the Evolution of International Order: Conceptualising Russia's Syria Policies', Europe-Asia Studies, 71:3, 365-87

President of Russia (2018a) 'Joint Statement by the President of the Islamic Republic of Iran, the President of the Russian Federation, the President of the Republic of Turkey', 7 September, <http://en.kremlin.ru/supplement/5337> accessed 5 June 2019

President of Russia (2018b) 'Joint statement by the presidents of the Republic of Turkey, the French Republic, the Russian Federation and the Chancellor of the Federal Republic of Germany', 27 October, <http://en.kremlin.ru/supplement/ $5351>$ accessed 5 December 2018

President of Russia (2019) 'Memorandum of Understanding Between Turkey and the Russian Federation', 22 October, <http://en.kremlin.ru/supplement/5452> accessed 5 November 2019

Qiblawi, Tamara (2018) 'All 'foreign forces' to leave Syria, Putin tells Assad', CNN, 18 May, <https://edition.cnn.com/2018/05/18/middleeast/assad-putin-intl/index. html $>$ accessed 5 November 2019

Reuters (2017) 'Turkey, Russia sign deal on supply of Russian S-400 missiles', 29 December, <https://www.reuters.com/article/us-russia-turkey-missiles/turkeyrussia-sign-deal-on-supply-of-s-400-missiles-idUSKBN1EN0T5 $>$ accessed 5 June 2019

Reuters (2018a) 'France's Macron says he persuaded Trump to keep troops in Syria', 15 April, $<$ https://www.reuters.com/article/us-mideast-crisis-syria-macron/frances-macronsay s-he-persuaded-trump-to-keep-troops-in-syria-idUSKBN1HM0X4> accessed 5 November 2019

Reuters (2018b) 'U.N. Says Astana Meeting on Syria a Missed Opportunity, No Progress', 29 November, <https://www.reuters.com/article/uk-mideast-crisissyria-talks/u-n-says-astana-meeting-on-syria-a-missed-opportunity-no-progressidUSKC

N1NY0VS $>$ accessed 5 June 2019

Reuters (2019a) 'Turkey Sends Weapons to Syrian Rebels Facing Russian-backed Assault: Syrian Sources', 25 May, <https://www.reuters.com/article/us-syriasecurity-idlib/turkey-sends-weapons-to-syrian-rebels-facing-russian-backed-assaultsyrian-sources-idUSKCN1SV0FA > accessed 5 June 2019

Reuters (2019b) 'Russia, Turkey agree steps to tackle militants in Syria's Idlib: Putin', 27 August, <https://www.reuters.com/article/us-syria-security-russia-turkey/russiaturkey-agree-steps-to-tackle-militants-in-syrias-idlib-putin-idUSKCN1VH0M8> accessed 5 November 2019

Reuters (2019c) 'Syria must be freed from military presence: Putin', 12 October, $<$ https://www.reuters.com/article/us-syria-security-putin/syria-must-be-freedfrom-foreign-military-presence-putin-idUSKBN1WR09X > accessed 5 November 2019

Rumelili, Bahar, and Ayşe Betül Çelik (2017) 'Ontological Insecurity in Asymmetric Conflicts: Reflections on Agonistic Peace in Turkey's Kurdish Issue', Security Dialogue, 48:4, 279-96

Russia Today (2015) 'Putin: Downing of Russian jet over Syria stab in the back by terrorist accomplices', 24 November, <https://www.rt.com/news/323262-putindowning-plane-syria/> accessed 5 June 2019

Sayar1, Sabri (2016) 'Back to a Predominant Party System: The November 2015 Snap Election in Turkey' South', South European Society and Politics, 21:2, 263-80

Snyder, Glenn H (1997) Alliance politics (Ithaca, NY and London: Cornell University Press) 
Sputnik News (2017) 'Full text of the Syrian Draft Constitution', 31 January, <https:/ / sputniknews.com/middleeast/201701311050216226-syrian-constitution-full-text/ $>$ accessed 5 June 2019

Stepanova, Ekaterina (2016) 'Russia's policy after the start of the military engagement', PONARS Eurasia Policy Memo No. 421, February 2016, <http://www. ponarseurasia.org/sites/default/files/policy-memos-pdf/Pepm421_Stepanova_Feb 2016.pdf $>$ accessed 5 June 2019

Stepanova, Ekaterina (2018) 'Russia and Conflicts in the Middle East: Regionalisation and Implications for the West', The International Spectator, 53:4, 35-57

Suchkov, Maxim (2019) 'Russia has 3 messages for Turkey over operation in Syria', Al Monitor, 8 October, <https://www.al-monitor.com/pulse/originals/2019/10/ russia-turkey-operation-syria-us-kurds.html > accessed 22 October 2019

Svarin, David (2015) 'Towards a Eurasian axis? Russia and Turkey between cooperation and competition', Global Affairs, 1:4-5, 381-98

T24 (2018) 'Dışişleri Bakanı Çavuşoğlu, Rusya için İlk Kez 'Stratejik Ortak' Ifadesini Kullandi', 25 Ağustos, <https://t24.com.tr/haber/disisleri-bakani-cavusoglu-rusyaicin-ilk-kez-stratejik-ortak-ifadesini-kullandi,685369> accessed 12 September 2019

TASS (2017a) 'Moscow says broad representation of Syrian opposition not ensured in Geneva', 7 March, <http://tass.com/politics/934466> accessed 11 June 2019

TASS (2017b) 'Fourth round of Astana talks end with de-escalation zones deal', 5 May, <http://tass.com/world/944724> accessed 11 June 2019

TASS (2018) 'Kremlin: Terrorism hotbed in Idlib does not bode well', 30 August, $<$ https:/ / tass.com/politics/1019278> accessed 11 June 2019

TASS (2019a) 'Turkish president promises to create security zone in Syria in coming months', 25 January, <https://tass.com/world/1041819> accessed 11 June 2019

TASS (2019b) 'Russia's Rosatom in talks over selling 49\% in Akkuyu NPP', 15 April, $<$ https://tass.com/economy/1053705> accessed 12 August 2019

TASS (2019c) 'On Schedule: Turkey says second delivery of S-400s to be completed in mid-September', 30 August, <https://tass.com/defense/1075750> accessed 12 September 2019

The Guardian (2018) 'Russia and Turkey set up Idlib buffer zone to protect civilians', 17 September, <https://www.theguardian.com/world/2018/sep/17/russia-andturkey-to-set-up-idlib-buffer-zone-to-protect-civilians> accessed 12 August 2019

The Guardian (2019a) 'Recep Tayyip Erdoğan proposes 'safe zone' for refugees in Syria', The Guardian, 24 September, <https:/ /www.theguardian.com/world/2019/sep/24/ erdogan-proposes-plan-for-refugee-safe-zone-in-syria > accessed 5 November 2019

The Guardian (2019b) 'Trump's Turkey deal hands power to Ankara and leaves Syrian Kurds for dead', 18 October, <https://www.theguardian.com/world/2019/oct/18/trumpsturkey-deal-hands-power-to-ankara-and-leaves-syrian-kurds-for-dead $>$ accessed 18 October 2019

The Ministry of Foreign Affairs of the Russian Federation (2016) 'Joint Statement by the Foreign Ministers of the Islamic Republic of Iran, the Russian Federation and the Republic of Turkey on Agreed Steps to Revitalize the Political Process to End the Syrian Conflict' 20 December, <http://www.mid.ru/en/foreign_policy/ news/-/asset_publisher/cKNonkJE02Bw/content/id/2573489> accessed 12 September 2019

The Moscow Times (2019) 'Russia says it's Turkey's duty to stop fighting in Syria's Idlib', 31 May, <https://www.themoscowtimes.com/2019/05/31/russia-says-itsturkeys-duty-to-stop-fighting-in-syrias-idlib-a65830> accessed 12 September 2019

United Nations (2015) 'United Nations Security Council Resolution 2254', 18 December, <https:/ / www.un.org/en/ga/search/view_doc.asp?symbol=S/RES / 2254(2015), accessed 12 September 2019

Walt, Stephen (1987) The origin of alliances (Ithaca, NY: Cornell University Press)

Wilkins, Thomas S (2008) 'Russo-Chinese Strategic Partnership: A New Form of Security Cooperation?', Contemporary Security Policy, 29:2, 358-383

Wilkins, Thomas S (2012) 'Alignment', not 'Alliance' - The Shifting Paradigm of International Security Cooperation: Toward a Conceptual Taxonomy of Alignment', Review of International Studies, 38:1, 53-76 
Wilson, Jeanne (2019) 'Russia's Relationship with China: The Role of Domestic and Ideational Factors', International Politics, 56:6, 778-794

Xinhua (2018) 'Turkey, Russia Vow to Enhance Strategic Partnership', 14 August, <http://www.xinhuanet.com/english/2018-08/14/c_137390036.htm> accessed 12 September 2019

Yetkin, Murat (2016) 'Story of secret diplomacy that ended Russia-Turkey jet crisis', Hürriyet Daily News, 9 August 